\title{
Vascular diameter and intima-media thickness to diameter ratio values of the carotid artery in 642 healthy children
}

\author{
Luisa Semmler $^{1}$ (1) $\cdot$ Heidi Weberruß ${ }^{1} \cdot$ Lisa Baumgartner $^{1} \cdot$ Raphael Pirzer $^{2} \cdot$ Renate Oberhoffer-Fritz $^{1}$
}

Received: 7 March 2020 / Revised: 11 August 2020 / Accepted: 18 August 2020 / Published online: 18 September 2020

(C) The Author(s) 2020

\begin{abstract}
In children, arterial alterations occur with increased intima-media thickness as well as vascular diameter enlargement. Both conditions correlate with higher cardiovascular risk in adults, and both the array and proportion of these alterations are important hemodynamic parameters. In terms of functional adaptation processes, they influence several arterial wall properties as for example the shear and tensile stress of the vessel. There are no reference values for the vascular diameter and intima-media thickness/diameter ratio of the carotid artery in children. Therefore, this study aimed to assess vascular diameter, intima-media thickness/diameter ratio and related tensile stress values in children and to further investigate the influence of sex, age, body mass index, and blood pressure. The parameters were measured with high-resolution semi-automated ultrasound. Sex- and agedependent values were calculated with the LMS method for a cross-sectional sample of 642 healthy, non-obese children aged $8-17$ years. The mean vascular diameter was $5.45 \pm 0.46 \mathrm{~mm}$; the median intima-media thickness/diameter ratio was 0.085 (0.079-0.092); the median tensile stress was 105.4 (95.2-116.4) $\mathrm{kPa}$. The vascular diameter and the tensile stress were higher, and the intima-media thickness/diameter ratio was lower in boys than in girls. In comparison to the normal weight study population the excludedobese children had a significantly higher diameter, a lower intima-media thickness/diameter ratio, and a higher tensile stress. In multiple regression analyses of diameter, intima-media thickness/diameter ratio, and tensile stress, all parameters were influenced by sex and body mass index. Furthermore, systolic and diastolic blood pressure significantly influenced the vascular diameter, and systolic blood pressure significantly influenced the intima-media thickness/diameter ratio.

Conclusion: This study is the first to report values for the diameter, the intima-media thickness/diameter ratio of the carotid artery, and the related tensile stress allowing a more differentiated view of cardiovascular adaptations as it combines structural and functional vascular parameters.
\end{abstract}

Communicated by Gregorio Paolo Milani

Electronic supplementary material The online version of this article (https://doi.org/10.1007/s00431-020-03785-3) contains supplementary material, which is available to authorized users.

Luisa Semmler

luisa.semmler@tum.de

Heidi Weberruß

heidi.weberruss@tum.de

Lisa Baumgartner

lisa.baumgartner@tum.de

Raphael Pirzer

raphael.pirzer@uni-wh.de
Renate Oberhoffer-Fritz

renate.oberhoffer@tum.de

1 Institute of Preventive Pediatrics, Technical University, Munich, Germany

2 Department of Anaesthesiology and Operative Intensive Care, University Hospital, Augsburg, Germany 
What is Known:

- Intima-media thickness and vascular diameter are related to a higher cardiovascular risk in adults

- The intima-media thickness/diameter ratio gives information about hemodynamic and functional vessel adaptation

What is New:

- Values for vascular diameter, intima-media thickness/diameter ratio, and tensile stress of the carotid artery in children are presented in this study

- Intima-media thickness as a surrogate marker for arterial health in children should be complemented by intima-media thickness/diameter ratio measurement

Keywords Cardiovascular disease $\cdot$ Carotid intima-media thickness/diameter ratio $\cdot$ Children $\cdot$ Vascular diameter

$\begin{array}{ll}\text { Abbreviations } \\ \text { BMI } & \text { Body mass index } \\ \text { BP } & \text { Blood pressure } \\ \text { CCA } & \text { Common carotid artery } \\ \text { CVD } & \text { Cardiovascular disease } \\ \text { D } & \text { Vascular diameter } \\ \text { DBP } & \text { Diastolic blood pressure } \\ \text { IDR } & \text { Intima-media thickness/diameter ratio } \\ \text { IMT } & \text { Intima-media thickness } \\ \text { MAP } & \text { Mean arterial pressure } \\ \text { SBP } & \text { Systolic blood pressure }\end{array}$

\section{Introduction}

Cardiovascular disease (CVD) accounts for approximately one-third of all deaths globally [1]. The leading cause of CVD is atherosclerosis, which may begin in childhood [2]. Carotid intima-media thickness (IMT) is an established surrogate marker to detect an altered arterial wall structure and subclinical atherosclerosis in children and adults [3]. Known risk factors for CVD are obesity [4], hypertension [5], familial hypercholesterolemia [6], type 1 diabetes [7], non-alcoholic fatty liver disease [8], chronic kidney disease [9], and inflammatory factors, such as HIV infection, treated with antiretroviral therapy [10], and increased serum C-reactive protein concentrations [11]. All these risk factors are associated with increased IMT in children. Moderate physical activity, a protective factor for CVD [12], was shown to decrease IMT in children [13]. In contrast, exercise can also lead to an increased IMT $[14,15]$ and was positively associated with cardiorespiratory fitness in children [16, 17]. Besides IMT, further vascular parameters exist that describe arterial properties. For example, in adults, there is an independent association between increased vascular diameter (D) and higher cardiovascular risk $[18,19]$. Respectively, a larger $\mathrm{D}$ of the common carotid artery (CCA) in childhood is associated with chronic kidney disease [9], obesity [20], metabolic syndrome [21], and hypertension [22]. The ratio between IMT and D can be specified as the intima-media thickness/diameter ratio (IDR). Adult arteries may adapt by increasing D to compensate for an atherosclerotic-induced thickening of IMT; thus, hemodynamically significant vessel narrowing can be prevented [23]. In a hemodynamic approach, shear and tensile stress are relevant determinants for arterial alterations. Shear stress refers to the velocity near the arterial wall that aligns the endothelium with the flow direction [24], and is influenced by viscosity, blood flow, and D [25]. Tensile stress is regarded as a stretching force perpendicular to a longitudinal section of the arterial wall and is approximated by distending pressure, D, and IMT [26]. Vessels can adapt by increasing D to restore altered shear stress induced for example by a higher flow rate. IMT may subsequently increase to maintain tensile stress [24, 27]. Because adaptations of IMT and D may not always occur simultaneously, monitoring both parameters and measuring their ratio, defined as IDR, can offer a more differentiated view of vascular changes. These parameters may indicate whether IMT and D adapt in terms of adequate remodeling or within a pathologic process $[28,29]$. In contrast to IMT, for which reference values exist [30-32], there are no reference values for $\mathrm{D}$ and IDR in children. Therefore, this study aimed to calculate sex- and age-dependent values for D, IDR, and related tensile stress of the CCA for 642 healthy children. Furthermore, the influence of sex, age, body mass index (BMI), and systolic and diastolic blood pressure (SBP, DBP) on D, IDR, and tensile stress was analyzed.

\section{Materials and methods}

\section{Participants}

The study was approved by the local ethics committee (5490/12) and met the ethical guidelines of the Declaration of Helsinki (revision 2013). Written informed consent was obtained from all children aged $\geq 14$ years and all participants' parents.

\section{Anthropometry and blood pressure}

Measurements of body mass and height were made to the nearest $0.1 \mathrm{~kg}$ and $0.1 \mathrm{~cm}$ (seca 799; seca, Hamburg, 
Germany), respectively, both without shoes and wearing light clothes. The BMI was calculated by body mass $(\mathrm{kg}) /$ height $(\mathrm{m})^{2}$. Children with a BMI $\geq 90$ th percentile were considered overweight, and those with a $\mathrm{BMI} \geq 97$ th percentile as obese [33]. After $10 \mathrm{~min}$ of rest, peripheral SBP and DBP were obtained using an oscillometer (Mobil-O-Graph, I.E.M.) on the left upper arm. All measurements were conducted by trained staff. Children with a single measurement $>$ 95th percentile [34] were not diagnosed with manifest, but with suspected hypertension. Mean arterial pressure (MAP) was calculated with the following formula: $\mathrm{MAP}=(\mathrm{DBP} \times$ $2+\mathrm{SBP}) / 3[35]$.

\section{IMT, D, and tensile stress}

IMT measurements were recorded using high-resolution, non-invasive, semi-automated B-Mode ultrasound. D was measured with the same device in M-Mode (ProSound Alpha 6; Aloka/Hitachi Medical Systems), both with a high-frequency linear array probe (5$13 \mathrm{MHz}$ ). The IMT was measured on the far wall of the CCA, $1 \mathrm{~cm}$ proximal to the bulb at the end-diastolic moment (R-wave), when IMT is thickest [36]. The vascular diameter was measured at the same location as IMT. The average minimum D value of the left and right CCA, which corresponds with end-diastolic IMT, was recorded from at least five heart cycles [36]. The IDR was calculated as the ratio between IMT and D. Further details of the measurement methodology are described elsewhere [31]. Tensile stress was calculated as $\mathrm{MAP} \times \mathrm{D} / 2 \times \mathrm{IMT}[37]$.

\section{Statistical analysis}

Statistical analysis was performed with the statistical software R Studio (version 1.1. 463, 2009-2018, RStudio). The parameters of the study population were expressed as mean \pm standard deviation (SD) or median and interquartile range (IQR) according to their distribution. The participants were clustered into five age groups (7.75-10.00, 10.00-11.99, 12.00-13.99, 14.0015.99, and 16.00-17.25 years). Sex differences in anthropometric data and sex-dependent differences concerning D, IDR, and tensile stress were analyzed using an independent two-sample $t$ test or MannWhitney $U$ test. Participants were furthermore clustered into three BMI groups, separated by sex (normal weight: BMI <90th percentile, overweight: BMI $\geq 90$ th and $<97$ th percentile, obese: BMI $\geq 97$ th percentile). The z-scores of D, IDR, and tensile stress were calculated for each BMI level (normal weight, overweight, and obese) according to the following formula:
$\mathrm{z}-\mathrm{score}=\frac{\left(\frac{x}{M}\right)^{L-1}}{L \times S}$ for $L \neq 0$ or
$\mathrm{z}-\mathrm{score}=\frac{\ln \left(\frac{x}{M}\right)}{S}$ for $L=0$

The differences in Z-scores regarding D, IDR, and tensile stress were calculated by an one-way analysis of variance or a Kruskal-Wallis test. The influence of sex, age, BMI, SBP, and DBP on D, IDR, and tensile stress was analyzed by a multiple linear regression. Sex- and age-dependent values for D, IDR, and tensile stress were estimated using GAMLSS (Generalized Additive Models for Location, Scale, and Shape) software, applying the LMS method [38]. A BoxCox Cole and Green distribution was assumed for the response variable to transform data into a normal distribution. The approximate median (M), the approximate coefficient of variation (S), and skewness (L) were all estimated [39]. A $p$ value $<0.05$ was considered statistically significant.

\section{Results}

\section{Participants}

Data were collected from October 2012 to July 2013 as part of the project "Sternstunden der Gesundheit" in a school-based setting in the region Berchtesgadener Land, Germany [31]. In total, 1017 healthy schoolchildren aged 7-18 years were examined. Due to technical problems, data were lost on IMT for 264 children, on D for 89 children, and on BP for one child. Furthermore, 14 participants aged $<7.75$ years or $\geq$ 17.25 years were excluded due to inadequate sample sizes. In addition, 45 obese children (BMI > 97th percentile [33]) were excluded from the analysis but considered for the comparison of D, IDR, and tensile stress between the different BMI groups. All together, valid data were available for 642 non-obese participants age 7.75-17.25 years (Fig. 1). For IMT, intertester variability was $4.79 \%$.

Female participants were significantly older $(p<0.001)$ and taller $(p=0.006)$ than male participants. For more details on the study population's characteristics, see Table 1. Nineteen girls and 30 boys were overweight, and 26 girls and 19 boys obese.

\section{Diameter}

The mean D was $5.45 \pm 0.46 \mathrm{~mm}$ for the total study population, $5.35 \pm 0.42 \mathrm{~mm}$ for girls, and $5.58 \pm 0.47 \mathrm{~mm}$ for boys. Mean \pm SD or median (IQR) values of D for the particular age groups are shown in Table S1 (Online Resource). Boys had significantly higher $\mathrm{D}$ values than girls in total and in all age groups except $14.00-15.99$ years (for all $p<0.05$ ). 
Fig. 1 Inclusion and exclusion of participants

\author{
all subjects \\ subjects with complete data \\ subjects aged $\geq 7.75$ and \\ $<17.25$ years \\ subjects without obesity
}

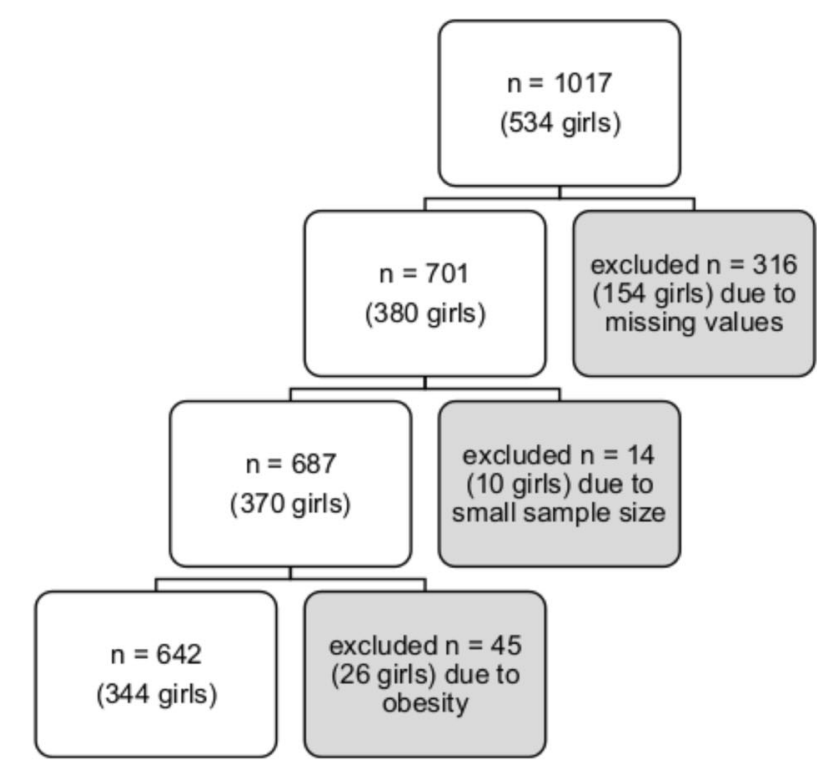

\section{IMT and IDR}

The IMT, but not the IDR, was normally distributed in the study population. The mean IMT of the total study population, and in both girls and boys, was $0.46 \pm$ $0.03 \mathrm{~mm}$. The median IDR was $0.085(0.079-0.092)$ for the entire study population, and 0.087 (0.081$0.093)$ for girls and $0.083(0.078-0.090)$ for boys, respectively. Mean $\pm \mathrm{SD}$ or median (IQR) values of IDR for the particular age groups are shown in Table S1 (Online Resource). Girls had a higher IDR than boys in total and in the age groups 10.00 11.99 years and $12.00-13.99$ years (for all $p<0.05$ ).

Table 1 Characteristics of study participants

\begin{tabular}{|c|c|c|c|c|}
\hline & $\begin{array}{l}\text { Total } \\
n=642 \\
\text { Mean } \pm \text { SD or median (IQR) }\end{array}$ & $\begin{array}{l}\text { Girls } \\
n=344 \\
\text { Mean } \pm \text { SD or median (IQR) }\end{array}$ & $\begin{array}{l}\text { Boys } \\
n=298 \\
\text { Mean } \pm \text { SD or median (IQR) }\end{array}$ & $p$ value \\
\hline Age (year) & $11.9(10.6-13.9)$ & $12.3(10.6-14.3)$ & $11.6(10.5-12.8)$ & $<0.001$ \\
\hline Height $(\mathrm{cm})$ & $153.0(142.0-163.0)$ & $156.0(143.5-164.0)$ & $150.5(140.5-160.0)$ & 0.006 \\
\hline Body mass (kg) & $42.6(33.4-51.9)$ & $44.3(33.8-52.4)$ & $40.3(33.0-50.1)$ & 0.051 \\
\hline BMI $\left(\mathrm{kg} / \mathrm{m}^{2}\right)$ & $17.9(16.3-20.2)$ & $18.2(16.4-20.1)$ & $17.8(16.2-20.3)$ & 0.520 \\
\hline SBP (mmHg) & $115.0(109.3-122.0)$ & $115.0(109.0-122.0)$ & $115.0(110.0-121.0)$ & 0.872 \\
\hline $\mathrm{DBP}(\mathrm{mmHg})$ & $67.9 \pm 8.1$ & $68.1 \pm 8.2$ & $67.6 \pm 8.0$ & 0.440 \\
\hline MAP (mmHg) & $83.8 \pm 7.6$ & $84.0 \pm 7.8$ & $83.6 \pm 7.5$ & 0.576 \\
\hline IMT (mm) & $0.46 \pm 0.03$ & $0.46 \pm 0.03$ & $0.46 \pm 0.03$ & 0.559 \\
\hline $\mathrm{D}(\mathrm{mm})$ & $5.45 \pm 0.46$ & $5.35 \pm 0.42$ & $5.58 \pm 0.47$ & $<0.001$ \\
\hline IDR & $0.085(0.079-0.092)$ & $0.087(0.081-0.093)$ & $0.083(0.078-0.090)$ & $<0.001$ \\
\hline Tensile stress $(\mathrm{kPa})$ & $105.4(95.2-116.4)$ & $103.3(94.1-112.8)$ & $108.4 \pm 16.2$ & 0.001 \\
\hline
\end{tabular}

Descriptive statistic of the study population with p-values indicating sex differences

$B M I$ body mass index, $D$ vascular diameter, $D B P$ diastolic blood pressure, $I D R$ intima-media thickness/diameter ratio, $I M T$ intima-media thickness, $I Q R$ interquartile range, $M A P$ mean arterial pressure, $S B P$ systolic blood pressure, $S D$ standard deviation 
Girls

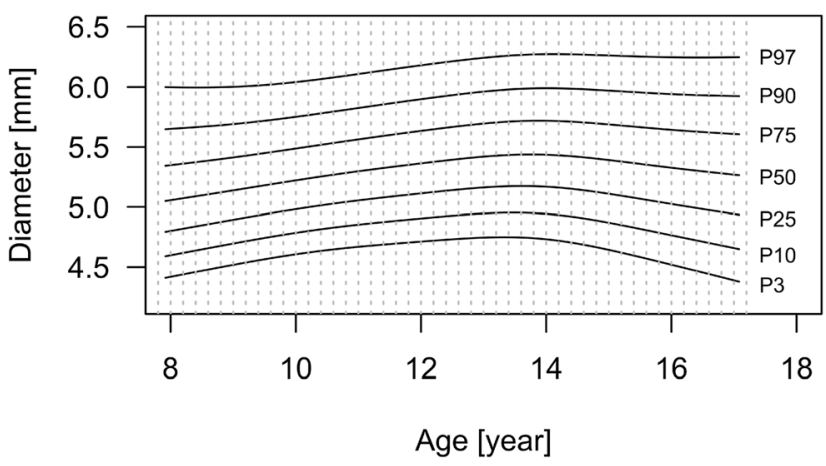

Boys

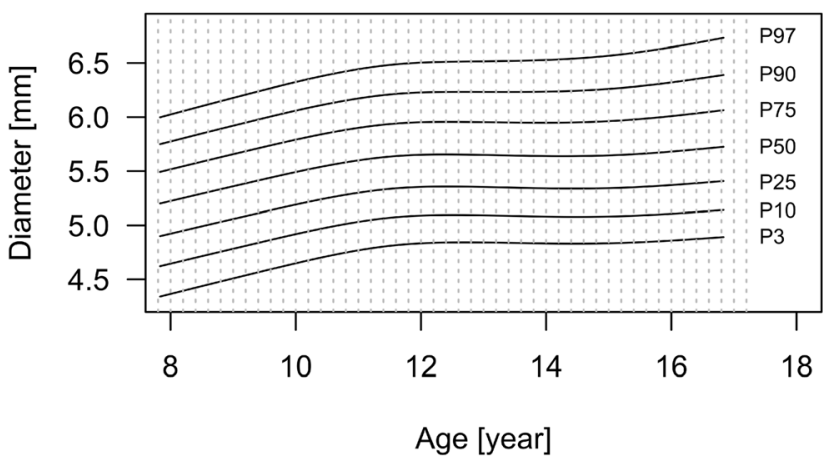

Fig. 2 Smoothed percentiles of vascular diameter (D) for girls and boys aged 8-17 years

Age-dependent values and corresponding L, M, and S scores for IDR are specified in Table S5 (Online Resource) for girls and Table S6 for boys (Online Resource). Figure 4 presents the corresponding smoothed fitted percentiles.

In multiple regression analysis, female sex and SBP were positively associated with IDR $(\beta=0.18, p<0.001 ; \beta=$ $0.13, p<0.001$, respectively), whereas BMI was negatively

Table 2 Multiple linear regression model for vascular diameter (D) and intima-media thickness/diameter ratio (IDR) and tensile stress.

\begin{tabular}{|c|c|c|c|c|}
\hline & $\beta$ & $\beta$ st & $p$ value & $95 \% \mathrm{CI}$ \\
\hline \multicolumn{5}{|c|}{ Model 1: $\mathrm{D}, R^{2}=0.22, \mathrm{p}<0.001$} \\
\hline Age & 0.00 & 0.00 & 0.962 & -0.02 to 0.02 \\
\hline Female sex & -0.24 & -0.26 & $<0.001$ & -0.30 to -0.17 \\
\hline BMI & 0.07 & 0.39 & $<0.001$ & 0.05 to 0.08 \\
\hline SBP & -0.01 & -0.12 & 0.006 & -0.01 to 0.00 \\
\hline DBP & 0.01 & 0.11 & 0.010 & 0.00 to 0.01 \\
\hline \multicolumn{5}{|c|}{ Model 2: IDR, $R^{2}=0.09, p<0.001$} \\
\hline Age & 0.00 & 0.06 & 0.187 & 0.00 to 0.00 \\
\hline Female sex & 0.00 & 0.18 & $<0.001$ & 0.00 to 0.00 \\
\hline BMI & 0.00 & -0.24 & $<0.001$ & 0.00 to 0.00 \\
\hline SBP & 0.00 & 0.13 & $<0.001$ & 0.00 to 0.00 \\
\hline DBP & 0.00 & -0.08 & 0.097 & 0.00 to 0.00 \\
\hline \multicolumn{5}{|c|}{ Model 3: tensile stress, $R^{2}=0.13, p<0.001$} \\
\hline Age & 1.89 & 0.08 & 0.059 & -0.02 to 1.22 \\
\hline Female sex & -3.93 & -0.15 & $<0.001$ & -7.22 to -2.41 \\
\hline BMI & 6.68 & 0.29 & $<0.001$ & 1.22 to 2.23 \\
\hline
\end{tabular}

Multiple regression analysis of D, IDR, and tensile stress with different influencing, anthropometric variables. Model 1: dependent variable: D, independent variables: age, female sex, BMI, SBP, DBP; Model 2: dependent variable: IDR, independent variables: age, female sex, BMI, SBP, DBP; Model 3: dependent variable: tensile stress, independent variables: age, female sex, BMI

$B M I$ body mass index, $C I$ confidence interval, $D$ vascular diameter, $D B P$ diastolic blood pressure, $I D R$ intima-media thickness/diameter ratio, $S B P$ systolic blood pressure, $\beta$ regression coefficients, $\beta$ st standardized regression coefficients, $R^{2}$ adjusted $\mathrm{R}^{2}$ associated with IDR $(\beta=-0.24, p<0.001)$. Age and DBP did not have a significant influence on IDR (Table 2).

Comparing the z-scores of IDR between the BMI groups, in girls, overweight and obese participants showed significantly lower IDR z-scores versus normal weight children (for all $p<0.001$ : Fig. 3, Table S4 Online Resource). In boys, only obese children showed significantly lower IDR z-scores than normal-weight boys $(p=0.002)$.

\section{Tensile stress}

The tensile stress was $105.4(95.2-116.4) \mathrm{kPa}$ for the total study population, $103.3(94.1-112.8) \mathrm{kPa}$ for girls and $108.4 \pm 16.2$ $\mathrm{kPa}$ for boys. Mean $\pm \mathrm{SD}$ or median (IQR) values of tensile stress for the particular age groups are shown in Table S1 (Online Resource). Girls had significantly lower tensile stress values than boys in total and in the age groups of 10.00 11.99 years and $16.00-17.25$ years (all $p<0.05$ ). Agedependent values and corresponding $\mathrm{L}, \mathrm{M}$, and $\mathrm{S}$ scores for tensile stress are specified in Table S7 for girls (Online Resource) and Table S8 for boys (Online Resource). Corresponding smoothed fitted percentiles are presented in Fig. S1 (Online Resource). In multiple regression analysis (Table 2), female sex was negatively associated with tensile stress $(\beta=-0.15, p<0.001)$, whereas BMI was positively associated with tensile stress $(\beta=0.29, p<0.001)$. Age had no significant influence on tensile stress. Comparing the z-scores of tensile stress between the BMI groups, overweight and obese participants showed significantly higher tensile stress z-scores than normal weight children in both, girls and boys (girls: normal weight vs. overweight $p=0.022$; boys normal weight vs. overweight $p=0.001$; normal weight vs. obese for both $p<0.001$ : Fig. S2 and Table S4 Online Resource).

\section{Discussion}

This study provides age- and sex-dependent values for D, IDR, and tensile stress of the CCA for a sample of 642 healthy, non- 
Diameter girls

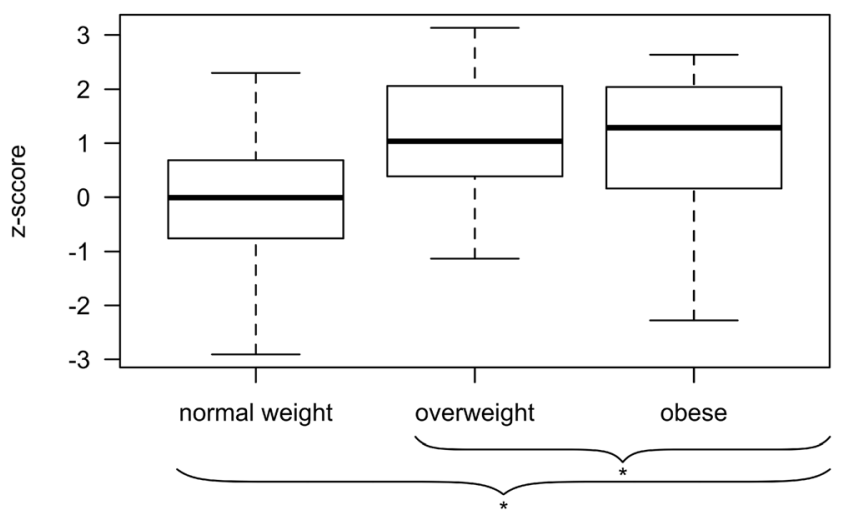

IDR girls

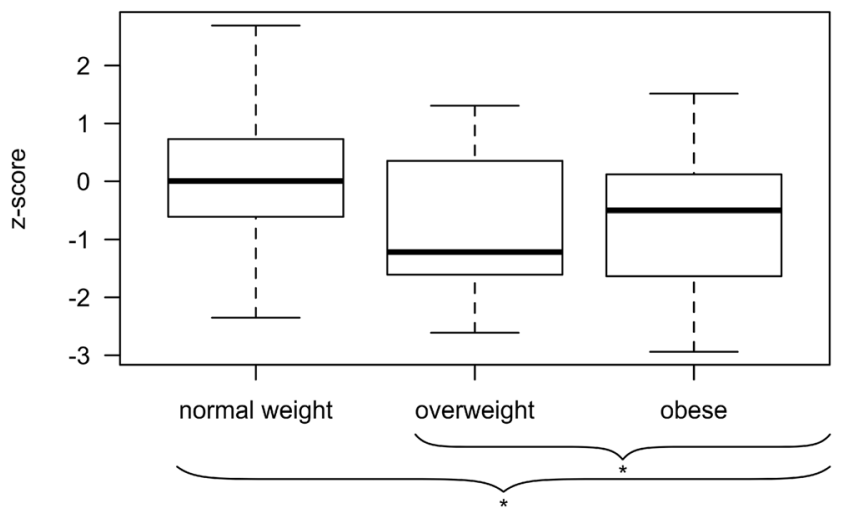

Diameter boys

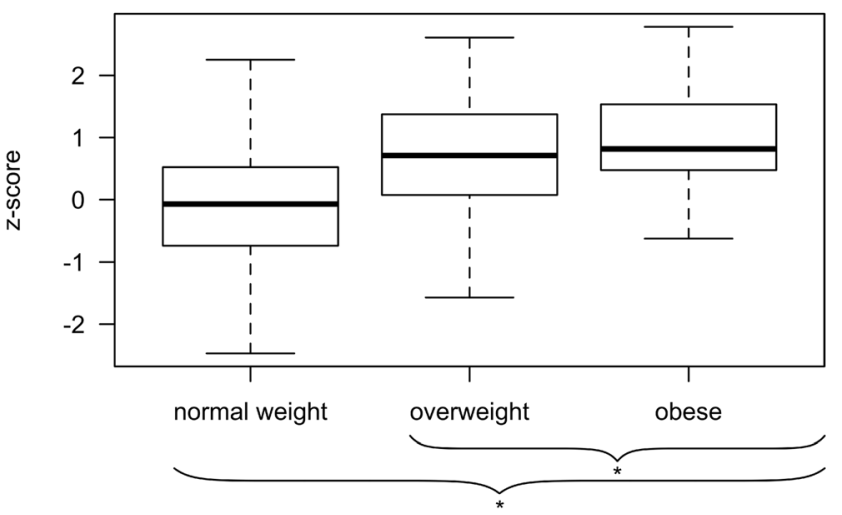

IDR boys

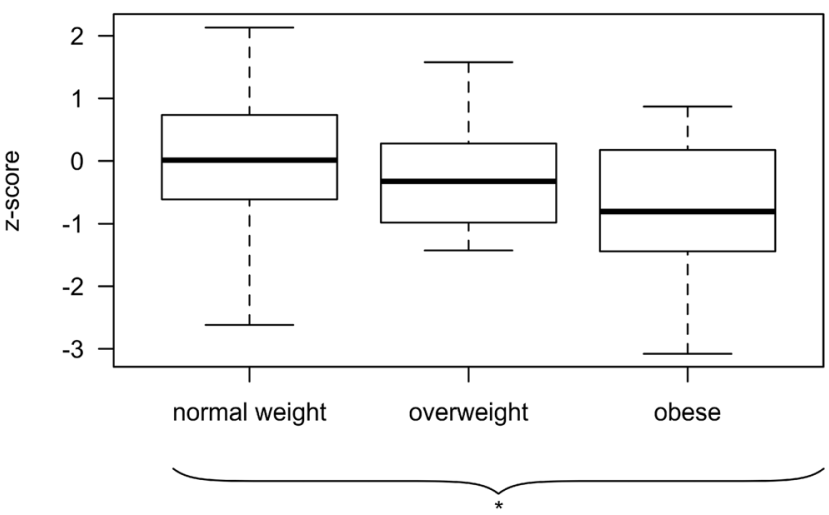

Fig. 3 Z-scores for vascular diameter (D) and intima-media thickness/diameter ratio (IDR) in normal weight, overweight, and obese girls and boys; $* p<0.05$

obese children and adolescents. To the best of the authors' knowledge, this is the first publication reporting D, IDR, and tensile stress values of the CCA in this population.

The findings for vascular parameters (IMT for the entire group $0.46 \pm 0.03 \mathrm{~mm}$; D girls $5.35 \pm 0.42 \mathrm{~mm}$, D boys $5.58 \pm$ $0.47 \mathrm{~mm}$ ) correspond well with those reported previously in the literature [40]. Nevertheless, conflicting results do exist due to methodological and population differences [22, 29, 40-43].

\section{Girls}

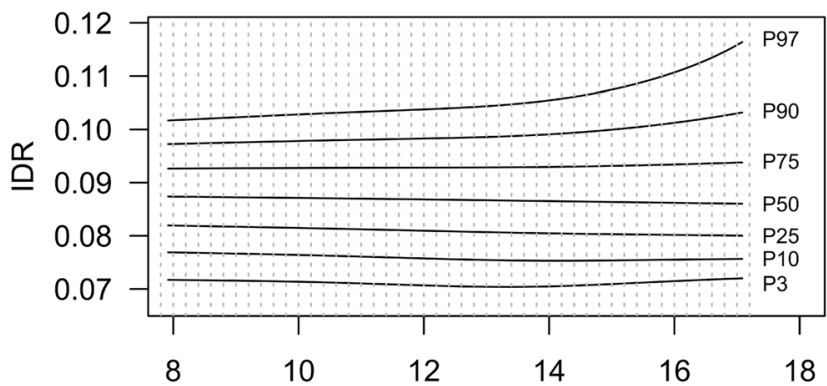

Age [year]
In multiple linear regression analysis, female sex was negatively associated with $\mathrm{D}$ and tensile stress but positively with IDR. In line with these findings, boys had higher D and tensile stress values than girls. In the literature, there were similar results for children [41, 42] and adolescents [44]. The sex difference in childhood for $\mathrm{D}$ is contrary to the findings for IMT, which seems not to differ between girls and boys in adolescence [31, 42], but only within adulthood [45]. Therefore, the authors of this study propose that the impact

\section{Boys}

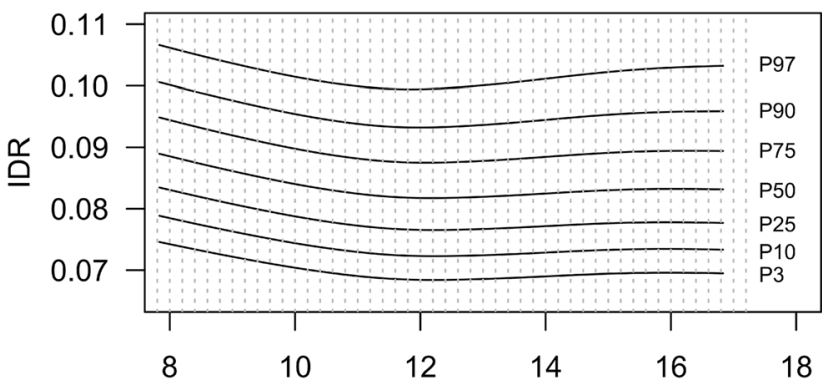

Age [year]

Fig. 4 Smoothed percentiles of intima-media thickness/diameter ratio (IDR) for girls and boys aged 8-17 years 
of sex on IDR and tensile stress may be predominantly based on interactions with arterial D. As the difference mainly occurs during the onset of puberty, hormonal influences on vascular tone and size could be a possible explanation for altered $\mathrm{D}$ values in boys and girls. Estrogen, progesterone, and testosterone receptors were detected in vascular cells in human arteries, which supports this hypothesis [46].

Consistent with the literature $[42,44]$, this study found significantly higher D z-scores for obese or overweight participants and a positive association of BMI with D and tensile stress. Even though both, IMT and D, are positively associated with a higher BMI [4], obese and overweight participants had a significantly lower IDR. Obesity is associated with increased blood flow and may lead to higher shear stress on the arterial wall [47]. This stress leads to an increased D through intracellular signaling processes [48]. In turn, an increased D may induce increased tensile stress with a subsequent IMT thickening [24]. Corresponding, a significantly higher tensile stress was found in obese and overweight girls and boys in this study population. Similar results were made by Chiesa et al. [29], who described an increased lumen, but a lower IMT with a reduced IDR and an increased tensile stress in obese young study participants. These findings indicate that risk factors for CVD, such as obesity, may be better explained by referring to IDR than IMT alone. Regarding the values of this healthy study population, a constant IDR over childhood can be assumed. In concordance, Chiesa et al. [29] suggested that increased fat-free mass is the predominant factor leading to a thickened IMT. In a growth-associated physiologic process, D increases as wellIDR, thereby, is kept at a constant level. Regarding the tensile stress in childhood, an inverse parabolic course of the graph can be observed in girls. The maximum tensile stress in 13-14year-old girls matches the physiological growth in puberty. Furthermore, in boys, tensile stress seems to increase by the age of 15-17 years, which would also fit the physiological growth-associated process in boys. As growth is not finished, anthropometric alterations lead to altered blood flow and BP [49] and may be the reason for temporary altered tensile stress. A thickened IMT in childhood seems more likely to occur due to functional adaptation processes to altered vascular conditions, rather than being the expression of pathologic subclinical atherosclerosis. Further studies are needed to work on several issues: first, to confirm the increase of the IMT and D as functional processes, and, secondly, to identify the trigger factors inducing these changes.

The impact of age and BP on vascular parameters is unclear. This study did not find a significant influence of age on D, IDR, or tensile stress which is in line with the results of Sass et al. [42]. In contrast, a positive influence of age on D in childhood was described previously $[40,41]$. Whether SBP or DBP is the predominant predictor for CVD remains unknown [50]. However, DBP seems to be the better parameter for evaluating the risk of CVD events at younger ages [51, 52]. CVD risk factors, such as sugar consumption [53], and IMT in young adolescents with insulin-dependent diabetes mellitus [53] are associated with increased DBP, but not SBP. Weberruss et al. [31] found a reduced acceleration of arterial stiffness and lower pulse pressure in children with higher DBP. The authors of the current study suggest a negative influence of SBP and a positive influence of DBP on D. Although only significant in girls, Sass et al. [42] found SBP to be a negative predictor of $\mathrm{D}$. In contrast, hypertensive boys, but not girls, showed a significant higher D versus normotensive peers in a study by Litwin et al. [22] (5.2 \pm 0.5 vs. $4.87 \pm$ $0.5, p=0.005)$. A positive influence of SBP on coronary IMT $[31,42]$ as well as on radial IMT [29] appears in the literature. These findings fit the current study results, revealing a positive influence of SBP on IDR. Further investigations are needed to elucidate the influencing factors on D and IDR.

The authors acknowledge several limitations of the present study. Presented values are based on a sample size of only 642 children. Separated by age group, the smallest age group cohort is 35 participants. Another methodologic limitation is the assessment of the vascular parameters on a single ultrasound machine, because these results may differ from measurements assessed with other ultrasound systems. The findings could only explain $9 \%$ of the variance of IDR with the parameters age, sex, BMI, SBP, and DBP. Especially for an adequate description of IDR, further influence factors on IMT and D must be taken into account. Higher IMT has been described in children and adolescents with the preload of familial hypercholesterolemia [6], increased concentrations of serum C-reactive protein [11], serum uric acid [54], plasma total homocysteine [55], increased cholesterol level [56], pubertal maturation [57], maternal obesity [58], parental smoking during pregnancy [59], severe intrauterine growth retardation [60], preterm birth [61, 62], and excess postnatal weight gain [63]. Therefore, these points should be investigated in future studies. Furthermore, participants with high BP values were not excluded from the analysis, although increased D and IMT were observed in children with hypertension [5]. To diagnose hypertension, at least three measurements of BP $>95$ th percentile must be assessed [64]. Because only one value was measured, this approach cannot exclude contributing factors such as "white-coat hypertension" [65]. The authors did not diagnose manifest, but suspected hypertension, in children with $\mathrm{BP}>95$ th percentile.

\section{Conclusion}

In conclusion, this study provides sex- and age-dependent values for D, IDR, and tensile stress of the CCA in 642 German children aged 8-17 years. These values may contribute to a more specific differentiation between the underlying 
processes of arterial wall alterations because both, structural and functional parameters are investigated.

Authors' contribution LS wrote the manuscript and performed statistical analysis and interpretation of the results. HW organized the study, collected the data, and provided the concept of this data analysis. LB provided the concept of this data analysis. RP collected the data. RO provided the concept of this study. All the authors reviewed the manuscript and approved the final version of the manuscript for publication.

Funding Open Access funding provided by Projekt DEAL.

\section{Compliance with ethical standards}

Conflict of interest The authors declare that they have no conflict of interest.

Ethics approval The study was approved by the local ethics committee $(5490 / 12)$ and meets the ethical guidelines of the Declaration of Helsinki (revision 2013).

Informed consent Written informed consent was obtained from all children aged $\geq 14$ years and all participants' parents.

Open Access This article is licensed under a Creative Commons Attribution 4.0 International License, which permits use, sharing, adaptation, distribution and reproduction in any medium or format, as long as you give appropriate credit to the original author(s) and the source, provide a link to the Creative Commons licence, and indicate if changes were made. The images or other third party material in this article are included in the article's Creative Commons licence, unless indicated otherwise in a credit line to the material. If material is not included in the article's Creative Commons licence and your intended use is not permitted by statutory regulation or exceeds the permitted use, you will need to obtain permission directly from the copyright holder. To view a copy of this licence, visit http://creativecommons.org/licenses/by/4.0/.

\section{References}

1. Joseph P, Leong D, McKee M, Anand SS, Schwalm JD, Teo K, Mente A, Yusuf S (2017) Reducing the global burden of cardiovascular disease, part 1: the epidemiology and risk factors. Circ Res 121(6):677-694. https://doi.org/10.1161/circresaha.117.308903

2. Berenson GS, Srinivasan SR, Bao W, Newman WP 3rd, Tracy RE, Wattigney WA (1998) Association between multiple cardiovascular risk factors and atherosclerosis in children and young adults. The Bogalusa Heart Study. N Engl J Med 338(23):1650-1656. https:// doi.org/10.1056/nejm199806043382302

3. Dalla Pozza R, Ehringer-Schetitska D, Fritsch P, Jokinen E, Petropoulos A, Oberhoffer R (2015) Intima media thickness measurement in children: a statement from the Association for European Paediatric Cardiology (AEPC) Working Group on Cardiovascular Prevention endorsed by the Association for European Paediatric Cardiology. Atherosclerosis 238(2):380-387. https://doi.org/10.1016/j.atherosclerosis.2014.12.029

4. Iannuzzi A, Licenziati MR, Acampora C, Salvatore V, Auriemma L, Romano ML, Panico S, Rubba P, Trevisan M (2004) Increased carotid intima-media thickness and stiffness in obese children. Diabetes Care 27(10):2506. https://doi.org/10.2337/diacare.27.10. 2506
5. Lande Marc B, Carson Nancy L, Roy J, Meagher Cecilia C (2006) Effects of childhood primary hypertension on carotid intima media thickness. Hypertension 48(1):40-44. https://doi.org/10.1161/01. HYP.0000227029.10536.e8

6. Lavrencic A, Kosmina B, Keber I, Videcnik V, Keber D (1996) Carotid intima-media thickness in young patients with familial hypercholesterolaemia. Heart 76(4):321-325. https://doi.org/10.1136/ hrt.76.4.321

7. Järvisalo MJ, Putto-Laurila A, Jartti L, Lehtimäki T, Solakivi T, Rönnemaa T, Raitakari OT (2002) Carotid artery intimA-media thickness in children with type 1 diabetes. Diabetes 51(2):493. https://doi.org/10.2337/diabetes.51.2.493

8. Pacifico L, Cantisani V, Ricci P, Osborn JF, Schiavo E, Anania C, Ferrara E, Dvisic G, Chiesa C (2008) Nonalcoholic fatty liver disease and carotid atherosclerosis in children. Pediatr Res 63(4):423427. https://doi.org/10.1203/PDR.0b013e318165b8e7

9. Litwin M, Wühl E, Jourdan C, Trelewicz J, Niemirska A, Fahr K, Jobs K, Grenda R, Wawer ZT, Rajszys P, Tröger J, Mehls O, Schaefer F (2005) Altered morphologic properties of large arteries in children with chronic renal failure and after renal transplantation. J Am Soc Nephrol 16(5):1494. https://doi.org/10.1681/ASN. 2004110932

10. McComsey GA, O'Riordan M, Hazen SL, El-Bejjani D, Bhatt S, Brennan M-L, Storer N, Adell J, Nakamoto DA, Dogra V (2007) Increased carotid intima media thickness and cardiac biomarkers in HIV infected children. AIDS 21(8):921-927. https://doi.org/10. 1097/QAD.0b013e328133f29c

11. Järvisalo Mikko J, Harmoinen A, Hakanen M, Paakkunainen U, Viikari J, Hartiala J, Lehtimäki T, Simell O, Raitakari Olli T (2002) Elevated serum C-reactive protein levels and early arterial changes in healthy children. Arterioscler Thromb Vasc Biol 22(8): 1323-1328. https://doi.org/10.1161/01.ATV.0000024222.06463. 21

12. Rangul V, Bauman A, Holmen TL, Midthjell K (2012) Is physical activity maintenance from adolescence to young adulthood associated with reduced CVD risk factors, improved mental health and satisfaction with life: the HUNT Study, Norway. Int J Behav Nutr Phys Act 9(1):144. https://doi.org/10.1186/1479-5868-9-144

13. Idris NS, Evelein AM, Geerts CC, Sastroasmoro S, Grobbee DE, Uiterwaal CS (2015) Effect of physical activity on vascular characteristics in young children. Eur J Prev Cardiol 22(5):656-664. https://doi.org/10.1177/2047487314524869

14. Mayet J, Stanton AV, Chapman N, Foale RA, Hughes AD, Thom SAMG (2002) Is carotid artery intima-media thickening a reliable marker of early atherosclerosis? J Cardiovasc Risk 9(2):77-81. https://doi.org/10.1177/174182670200900202

15. Feairheller DL, Aichele KR, Oakman JE, Neal MP, Cromwell CM, Lenzo JM, Perez AN, Bye NL, Santaniello EL, Hill JA, Evans RC, Thiele KA, Chavis LN, Getty AK, Wisdo TR, McClelland JM, Sturgeon K, Chlad P (2016) Vascular health in American football players: cardiovascular risk increased in division III players. Int $\mathrm{J}$ Vasc Med 2016:6851256. https://doi.org/10.1155/2016/6851256

16. Weberruss H, Pirzer R, Schulz T, Bohm B, Dalla Pozza R, Netz H, Oberhoffer R (2017) Reduced arterial stiffness in very fit boys and girls. Cardiol Young 27(1):117-124. https://doi.org/10.1017/ s1047951116000226

17. Baumgartner L, Weberruß H, Oberhoffer-Fritz R, Schulz T (2020) Vascular structure and function in children and adolescents: what impact do physical activity, health-related physical fitness, and exercise have? Front Pediatr 8(103). https://doi.org/10.3389/fped. 2020.00103

18. Eigenbrodt ML, Sukhija R, Rose KM, Tracy RE, Couper DJ, Evans GW, Bursac Z, Mehta JL (2007) Common carotid artery wall thickness and external diameter as predictors of prevalent and incident cardiac events in a large population study. Cardiovasc Ultrasound 5:11-11. https://doi.org/10.1186/1476-7120-5-11 
19. Sedaghat S, van Sloten TT, Laurent S, London GM, Pannier B, Kavousi M, Mattace-Raso F, Franco OH, Boutouyrie P, Ikram MA, Stehouwer CDA (2018) Common carotid artery diameter and risk of cardiovascular events and mortality: pooled analyses of four cohort studies. Hypertension 72(1):85-92. https://doi.org/ 10.1161/hypertensionaha.118.11253

20. Tounian P, Aggoun Y, Dubern B, Varille V, Guy-Grand B, Sidi D, Girardet J-P, Bonnet D (2001) Presence of increased stiffness of the common carotid artery and endothelial dysfunction in severely obese children: a prospective study. Lancet 358(9291):1400 1404. https://doi.org/10.1016/S0140-6736(01)06525-4

21. Iannuzzi A, Licenziati MR, Acampora C, De Michele M, Iannuzzo G, Chiariello G, Covetti G, Bresciani A, Romano L, Panico S, Rubba P (2008) Carotid artery wall hypertrophy in children with metabolic syndrome. J Hum Hypertens 22(2):83-88. https://doi. org/10.1038/sj.jhh.1002289

22. Litwin M, Trelewicz J, Wawer Z, Antoniewicz J, Wierzbicka A, Rajszys P, Grenda R (2004) Intima-media thickness and arterial elasticity in hypertensive children: controlled study. Pediatr Nephrol 19(7):767-774. https://doi.org/10.1007/s00467-0041480-6

23. Labropoulos N, Zarge J, Mansour MA, Kang SS, Baker WH (1998) Compensatory arterial enlargement is a common pathobiologic response in early atherosclerosis. Am J Surg 176(2):140-143. https:// doi.org/10.1016/s0002-9610(98)00135-4

24. Bots ML, Hofman A, Grobbee DE (1997) Increased common carotid intima-media thickness. Adaptive response or a reflection of atherosclerosis? Findings from the Rotterdam Study. Stroke 28(12): 2442-2447. https://doi.org/10.1161/01.str.28.12.2442

25. Paszkowiak JJ, Dardik A (2003) Arterial wall shear stress: observations from the bench to the bedside. Vasc Endovasc Surg 37(1): 47-57. https://doi.org/10.1177/153857440303700107

26. Chironi GN, Simon A, Bokov P, Levenson J (2009) Correction of carotid intima-media thickness for adaptive dependence on tensile stress: implication for cardiovascular risk assessment. J Clin Ultrasound 37(5):270-275. https://doi.org/10.1002/jcu.20578

27. Glagov S, Vito R, Giddens DP, Zarins CK (1992) Microarchitecture and composition of artery walls: relationship to location, diameter and the distribution of mechanical stress. J Hypertens Suppl 10(6):S101-S104

28. Bots ML, Grobbee DE, Hofman A, Witteman JC (2005) Common carotid intima-media thickness and risk of acute myocardial infarction: the role of lumen diameter. Stroke 36(4):762-767. https://doi. org/10.1161/01.Str.0000158924.71069.94

29. Chiesa ST, Charakida M, Georgiopoulos G, Dangardt F, Wade KH, Rapala A, Bhowruth DJ, Nguyen HC, Muthurangu V, Shroff R, Davey Smith G, Lawlor DA, Sattar N, Timpson NJ, Hughes AD, Deanfield JE (2019) Determinants of intima-media thickness in the young. JACC Cardiovasc Imaging 3219. https://doi.org/10.1016/j. jcmg.2019.08.026

30. Doyon A, Kracht D, Bayazit Aysun K, Deveci M, Duzova A, Krmar Rafael T, Litwin M, Niemirska A, Oguz B, Schmidt Bernhard MW, Sözeri B, Querfeld U, Melk A, Schaefer F, Wühl E (2013) Carotid artery intima-media thickness and distensibility in children and adolescents. Hypertension 62(3):550-556. https://doi. org/10.1161/HYPERTENSIONAHA.113.01297

31. Weberruss H, Pirzer R, Bohm B, Elmenhorst J, Pozza RD, Netz H, Oberhoffer R (2015) Increased intima-media thickness is not associated with stiffer arteries in children. Atherosclerosis 242(1):4855. https://doi.org/10.1016/j.atherosclerosis.2015.06.045

32. Jourdan C, Wühl E, Litwin M, Fahr K, Trelewicz J, Jobs K, Schenk J-P, Grenda R, Mehls O, Tröger J, Schaefer F (2005) Normative values for intima-media thickness and distensibility of large arteries in healthy adolescents. J Hypertens 23:1707-1715. https://doi.org/ 10.1097/01.hjh.0000178834.26353.d5
33. Kromeyer-Hauschild K, Wabitsch M, Kunze D, Geller F, Geiß HC, Hesse V, von Hippel A, Jaeger U, Johnsen D, Korte W, Menner K, Müller G, Müller JM, Niemann-Pilatus A, Remer T, Schaefer F, Wittchen HU, Zabransky S, Zellner K, Ziegler A, Hebebrand J (2001) Perzentile für den body-mass-index für das Kindes- und Jugendalter unter Heranziehung verschiedener deutscher Stichproben. Monatsschrift Kinderheilkunde 149(8):807-818. https://doi.org/10.1007/s001120170107

34. Neuhauser HK, Thamm M, Ellert U, Hense HW, Rosario AS (2011) Blood pressure percentiles by age and height from nonoverweight children and adolescents in Germany. Pediatrics 127(4):e978-e988. https://doi.org/10.1542/peds.2010-1290

35. Franklin Stanley S, Lopez Victor A, Wong Nathan D, Mitchell Gary F, Larson Martin G, Vasan Ramachandran S, Levy D (2009) Single versus combined blood pressure components and risk for cardiovascular disease. Circulation 119(2):243-250. https://doi. org/10.1161/CIRCULATIONAHA.108.797936

36. Touboul PJ, Hennerici MG, Meairs S, Adams H, Amarenco P, Bornstein N, Csiba L, Desvarieux M, Ebrahim S, Hernandez Hernandez R, Jaff M, Kownator S, Naqvi T, Prati P, Rundek T, Sitzer M, Schminke U, Tardif JC, Taylor A, Vicaut E, Woo KS (2012) Mannheim carotid intima-media thickness and plaque consensus (2004-2006-2011). An update on behalf of the advisory board of the 3rd, 4th and 5th watching the risk symposia, at the 13th, 15th and 20th European Stroke Conferences, Mannheim, Germany, 2004, Brussels, Belgium, 2006, and Hamburg, Germany, 2011. Cerebrovasc Dis 34(4):290-296. https://doi.org/ $10.1159 / 000343145$

37. Bussy C, Boutouyrie P, Lacolley P, Challande P, Laurent S (2000) Intrinsic stiffness of the carotid arterial wall material in essential hypertensives. Hypertension 35(5):1049-1054. https://doi.org/10. 1161/01.HYP.35.5.1049

38. Cole TJ, Green PJ (1992) Smoothing reference centile curves: the LMS method and penalized likelihood. Stat Med 11(10):13051319. https://doi.org/10.1002/sim.4780111005

39. Stasinopoulos DM (2017) Flexible regression and smoothing: using GAMLSS in R. Taylor \& Francis Group, LLC, Boca Raton. https:// doi.org/10.1201/b21973

40. Ishizu T, Ishimitsu T, Yanagi H, Seo Y, Obara K, Moriyama N, Watanabe S, Yamaguchi I (2004) Effect of age on carotid arterial intima-media thickness in childhood. Heart Vessel 19(4):189-195. https://doi.org/10.1007/s00380-004-0766-8

41. Sarkola T, Manlhiot C, Slorach C, Bradley TJ, Hui W, Mertens L, Redington A, Jaeggi E (2012) Evolution of the arterial structure and function from infancy to adolescence is related to anthropometric and blood pressure changes. Arterioscler Thromb Vasc Biol 32(10): 2516-2524. https://doi.org/10.1161/atvbaha.112.252114

42. Sass C, Herbeth B, Chapet O, Siest G, Visvikis S, Zannad F (1998) Intima-media thickness and diameter of carotid and femoral arteries in children, adolescents and adults from the Stanislas cohort: effect of age, sex, anthropometry and blood pressure. J Hypertens 16(11): 1593-1602

43. Hansen F, Mangell P, Sonesson B, Lanne T (1995) Diameter and compliance in the human common carotid artery-variations with age and sex. Ultrasound Med Biol 21(1):1-9. https://doi.org/10. 1016/0301-5629(94)00090-5

44. Ruan L, Chen W, Srinivasan SR, Sun M, Wang H, Toprak A, Berenson GS (2009) Correlates of common carotid artery lumen diameter in black and white younger adults: the Bogalusa Heart Study. Stroke 40(3):702-707. https://doi.org/10.1161/strokeaha. 108.531608

45. Stensland-Bugge E, Bønaa KH, Joakimsen O (2001) Age and sex differences in the relationship between inherited and lifestyle risk factors and subclinical carotid atherosclerosis: the Tromsø study. Atherosclerosis 154(2):437-448. https://doi.org/10.1016/S00219150(00)00486-X 
46. Thompson J, Khalil RA (2003) Gender differences in the regulation of vascular tone. Clin Exp Pharmacol Physiol 30:1-2):1-1-2)15. https://doi.org/10.1046/j.1440-1681.2003.03790.x

47. Chung WB, Hamburg NM, Holbrook M, Shenouda SM, Dohadwala MM, Terry DF, Gokce N, Vita JA (2009) The brachial artery remodels to maintain local shear stress despite the presence of cardiovascular risk factors. Arterioscler Thromb Vasc Biol 29(4):606-612. https://doi.org/10.1161/ATVBAHA.108.181495

48. Lehoux S, Castier Y, Tedgui A (2006) Molecular mechanisms of the vascular responses to haemodynamic forces. J Intern Med 259(4):381-392. https://doi.org/10.1111/j.1365-2796.2006.01624. $\mathrm{x}$

49. Wade Kaitlin H, Chiesa Scott T, Hughes Alun D, Chaturvedi N, Charakida M, Rapala A, Muthurangu V, Khan T, Finer N, Sattar N, Howe Laura D, Fraser A, Lawlor Debbie A, Davey Smith G, Deanfield John E, Timpson Nicholas J (2018) Assessing the causal role of body mass index on cardiovascular health in young adults. Circulation 138(20):2187-2201. https://doi.org/10.1161/ CIRCULATIONAHA.117.033278

50. Alderman MH (1999) A new model of risk: implications of increasing pulse pressure and systolic blood pressure on cardiovascular disease. J Hypertens Suppl 17(5):S25-S28

51. Tverdal A (1987) Systolic and diastolic blood pressures as predictors of coronary heart disease in middle aged Norwegian men. $\mathrm{Br}$ Med J (Clin Res Ed) 294(6573):671-673. https://doi.org/10.1136/ bmj.294.6573.671

52. Kannel WB, Gordon T, Schwartz MJ (1971) Systolic versus diastolic blood pressure and risk of coronary heart disease. The Framingham study. Am J Cardiol 27(4):335-346. https://doi.org/ 10.1016/0002-9149(71)90428-0

53. Kell KP, Cardel MI, Bohan Brown MM, Fernández JR (2014) Added sugars in the diet are positively associated with diastolic blood pressure and triglycerides in children. Am J Clin Nutr 100(1):46-52. https://doi.org/10.3945/ajcn.113.076505

54. Bassols J, Martínez-Calcerrada JM, Prats-Puig A, Carreras-Badosa G, Díaz-Roldán F, Osiniri I, Riera-Pérez E, de Zegher F, Ibáñez L, López-Bermejo A (2016) Uric acid, carotid intima-media thickness and body composition in prepubertal children. Pediatr Obesity 11(5):375-382. https://doi.org/10.1111/ijpo.12074

55. Tonstad S, Joakimsen O, Stensland-Bugge E, Leren TP, Ose L, Russell D, Bonaa KH (1996) Risk factors related to carotid intima-media thickness and plaque in children with familial hypercholesterolemia and control subjects. Arterioscler Thromb Vasc Biol 16(8):984-991. https://doi.org/10.1161/01.atv.16.8.984

56. Pauciullo P, Iannuzzi A, Sartorio R, Irace C, Covetti G, Di Costanzo A, Rubba P (1994) Increased intima-media thickness of the common carotid artery in hypercholesterolemic children. Arterioscler Thromb 14(7):1075-1079. https://doi.org/10.1161/ 01.ATV.14.7.1075
57. Zanini JLSS, Rodrigues TMB, Barra CB, Filgueiras MFTF, Silva IN (2019) Intima-media thickness of the carotid arteries is affected by pubertal maturation in healthy adolescents. Revista paulista de pediatria : orgao oficial da Sociedade de Pediatria de Sao Paulo 37(4):428-434. https://doi.org/10.1590/1984-0462/;2019;37;4; 00010

58. Sundholm JKM, Litwin L, Rono K, Koivusalo SB, Eriksson JG, Sarkola T (2019) Maternal obesity and gestational diabetes: impact on arterial wall layer thickness and stiffness in early childhood RADIEL study six-year follow-up. Atherosclerosis 284:237-244. https://doi.org/10.1016/j.atherosclerosis.2019.01.037

59. Geerts CC, Bots ML, van der Ent CK, Grobbee DE, Uiterwaal CSPM (2012) Parental smoking and vascular damage in their 5year-old children. Pediatrics 129(1):45-54. https://doi.org/10.1542/ peds.2011-0249

60. Oren A, Vos LE, Uiterwaal CSPM, Gorissen WHM, Grobbee DE, Bots ML (2004) Birth weight and carotid intima-media thickness: new perspectives from the atherosclerosis risk in young adults (ARYA) study. Ann Epidemiol 14(1):8-16. https://doi.org/10. 1016/S1047-2797(03)00068-1

61. Skilton Michael R, Viikari Jorma SA, Juonala M, Laitinen T, Lehtimäki T, Taittonen L, Kähönen M, Celermajer David S, Raitakari Olli T (2011) Fetal growth and preterm birth influence cardiovascular risk factors and arterial health in young adults. Arterioscler Thromb Vasc Biol 31(12):2975-2981. https://doi.org/ 10.1161/ATVBAHA.111.234757

62. Lee H, Dichtl S, Mormanova Z, Dalla Pozza R, GenzelBoroviczeny O (2014) In adolescence, extreme prematurity is associated with significant changes in the microvasculature, elevated blood pressure and increased carotid intima-media thickness. Arch Dis Child 99(10):907. https://doi.org/10.1136/archdischild-2013304074

63. Evelein AMV, Visseren FLJ, van der Ent CK, Grobbee DE, Uiterwaal CSPM (2013) Excess early postnatal weight gain leads to thicker and stiffer arteries in young children. J Clin Endocrinol Metab 98(2):794-801. https://doi.org/10.1210/jc.2012-3208

64. Lurbe E, Agabiti-Rosei E, Cruickshank JK, Dominiczak A, Erdine S, Hirth A, Invitti C, Litwin M, Mancia G, Pall D, Rascher W, Redon J, Schaefer F, Seeman T, Sinha M, Stabouli S, Webb NJ, Wuhl E, Zanchetti A (2016) 2016 European Society of Hypertension guidelines for the management of high blood pressure in children and adolescents. J Hypertens 34(10):1887-1920. https:// doi.org/10.1097/hjh.0000000000001039

65. Jurko A Jr, Minarik M, Jurko T, Tonhajzerova I (2016) White coat hypertension in pediatrics. Ital J Pediatr 42:4. https://doi.org/10. 1186/s13052-016-0213-3

Publisher's note Springer Nature remains neutral with regard to jurisdictional claims in published maps and institutional affiliations. 